\title{
A midiatização da (não) preservação: reflexões metodológicas sobre sociedade, periodismo e internet a propósito da demolição do Palácio Monroe
}

\section{Fernando Atique ${ }^{2}$}

RESUMO: Tem sido uma constante no campo patrimonial a exortação de que as políticas do patrimônio precisam se aproximar dos anseios preservacionistas da população. Este artigo procura discutir essa máxima, analisando as razões para a demanda pró-preservação de não especialistas do Palácio Monroe, obra de arquitetura erigida pelo governo brasileiro em 1904, nos EUA, remontada no Brasil, em 1906, e demolida em 1976. Como forma de entender a percepção da sociedade sobre o patrimônio, procura-se mostrar como o processo de demolição do Monroe mobilizou a sociedade carioca. $\bigcirc$ objetivo é compreender a produção de memória e da história do Rio por pessoas que não pertencem às agências oficiais do patrimônio e que podem, como resultado, permitir que o circuito social da arquitetura seja incorporado às discussões do campo do patrimônio.

PALAVRAS-CHAVE: Palácio Monroe. Demolição. Iphan. Rio de Janeiro. Imprensa. Internet.

ABSTRACT: Many scholars have pointed that the preservation policies should contemplate the society desires. This article discusses this maximum analyzing the reasons that produced demands from non-specialists about the preservation of the Monroe Palace. This building, that originally was built by the Brazilian government in 1904, in the US, was reassembled in Rio de Janeiro in 1906 and demolished in 1976. In order to understand the perception of society about this building, this paper seeks to show how the Monroe's demolition mobilized Rio society. Taking this episode about the (non-) preservation of this architecture, we developed some reflections on the role of the journalism, blogs and websites, framed by one methodological preoccupation. The goal is to comprehend the production of the Rio's memory and history by people that do not belong to official agencies of heritage in that city and, as result, to allow the discussion about the social circuit of the architecture within the heritage field.

\begin{abstract}
1. Este artigo é uma versão revista e ampliada daquela publicada nos Anais do III Encontro Nacional da Associação Nacional de Pesquisa e Pós-graduação em Arquitetura e Urbanismo (Anparq), ocorrido em São Paulo, em 2014. A pesquisa foi financiada pela Fundação de Amparo à Pesquisa do Estado de São Paulo (Fapesp) - Processo $2013 / 05080-2$.

2. Arquiteto e urbanista, docente na graduação e na pós-graduação do Departamento de História da Escola de Filosofia, Letras e Ciências Humanas da Universidade Federal de São Paulo (Unifesp). Co-coordenador do Grupo de Pesquisa CAPPH, sediado na mesma instituição. E-mail: <fernando.atique@ unifesp.br>.
\end{abstract}

KEYWORDS: Monroe Palace. Demolition. Iphan. Rio de Janeiro. Press. Internet. 
Los blogs, Twitter, las redes sociales, Wikileaks, los buscadores, los filtros sociales y los agregadores, así como cada innovación

que acabe siendo finalmente adoptada, son en su conjunto desafíos que cuestionan las funciones clásicas del periodismo y su papel social. (ORIHUELA, 2011 )

Imprensa e desaparecimentos

A teorização da arquitetura, nos últimos anos, voltou-se a uma dimensão que, supostamente, não dizia respeito à ideia mais tradicional sobre o que seria a produção do espaço. Vista como sinônimo de construção e experimentação plástica, a arquitetura, nos clássicos estudos que a problematizam, foi abordada a partir das relações projetivas verificáveis entre concepção espacial, cidade, materiais e, em alguns casos, entre clientes e projetistas. Contudo, uma dimensão mais social, ligada à percepção das obras de arquitetura para além do ambiente específico de sua produção, pouco atraiu a atenção dos historiadores até anos recentes. Essa afirmação diz respeito não apenas aos arquitetos que se especializaram em história, mas também aos historiadores que se dedicaram a historiar a arquitetura. Apenas nas duas últimas décadas houve o surgimento de scholars que se voltaram a perguntar: "como a arquitetura e as cidades foram vistas para além do ambiente de sua produção?"

Essa pergunta deflagrou, necessariamente, uma redefinição metodológica nos estudos de teoria, história e crítica da arquitetura. Impactante reviravolta, então, fez-se sentir nos programas de pós-graduação, e no incremento de publicações especializadas, que passaram a tratar questões como a produção da cidade, a ideia de domesticidade, as biografias profissionais com ênfase nas relações comerciais entre projetista e demandantes, etc ICARVALHO, 2015; SILVA, 2012; ATIQUE, 2013; OLIVEIRA, 2005; MARINS, 20011. Muito recentemente, tem surgido uma outra dimensão, notoriamente derivada da atitude metodológica acima narrada, que é a de averiguar como as obras de arquitetura parecem não desaparecer da memória coletiva, mesmo depois de demolidas (AMORIM, 2007; HERNÁNDEZ-MARTíNEZ, 2007; ALLUCCI, 2014). A grande disseminação da internet, a partir dos anos 2000, em especial no Brasil, possibilitou a emergência de formas de divulgação de informações, relatos, memórias, imagens e críticas que não alcançavam a Academia, e, que, muitas vezes, vagavam em dimensões orais, dentro de universos familiares. A internet, entretanto, estabeleceu redes, fidelizou leitores, encontrou conexões e reconfigurou toda uma dimensão social da arquitetura que há vinte anos era impossível de ser estudada. 
Este artigo, então, apresenta os resultados de uma investigação sobre essa dimensão de um novo tipo de periodismo: o digital, encontrado em websites, blogs, fotologs, páginas de redes sociais, e que tem por ponto específico a apresentação de imagens, relatos, críticas e fontes sobre arquitetura.

Assim, tomando a epígrafe deste texto, podemos introduzir a questão central deste artigo, que é mostrar que uma obra de arquitetura é mais do que uma cristalização de um discurso hermético, restrito aos profissionais desse campo do conhecimento. Essa assertiva está embasada na percepção de que a arquitetura molda a cidade, pois embora seja, sim, discurso formal e funcional, é, também, imagem, depositório de representações, deflagrador de memórias e suporte material de referenciais urbanos. Essa nova forma de periodismo pode ser tomada como uma das maneiras pelas quais a sociedade organiza suas representações, permitindo ao historiador a criação de uma janela privilegiada para perguntas de caráter histórico, que na imprensa tradicional, basicamente a jornalística, não seria de todo passível de obtenção. Como foco mais específico de investigação, então, tomamos como estudo os relatos da sociedade carioca acerca da demolição do Palácio Monroe, em 1976.

Antes de tudo, devemos enfatizar que o estudo da não preservação é de caráter metodológico. Nesse sentido, os domínios da História, e, em especial, de uma possível "História Social da Cultura Preservacionista" nos delineiam um percurso menos hermético e com fortes situações didáticas. Essa dimensão histórica e historiográfica com que procuramos abordar as edificações que se esvaíram impõe, assim, ao historiador urbano e da arquitetura o desenvolvimento de um aporte teórico. Dessa maneira, torna-se importante refletir que a discussão acerca do desaparecimento é, em si, quase uma metáfora do fazer histórico, pois, assim como lembrar tem seu avesso no esquecer, o edificar encontra antítese no demolir. Defende-se, então, que a discussão atinente à preservação brasileira precisa incorporar também as razões que levaram edifícios ao desaparecimento. Assim, negativas de tombamento, acidentes supostamente fortuitos e tragédias naturais podem ser historiados favorecendo uma revisão dos trâmites institucionais preservacionistas. Esta é a grande contribuição que a história da "não preservação" tem a dar na definição de estratégicas culturais e de políticas públicas, mas também na reflexão metodológica acerca da escrita da história da arquitetura e das cidades.

Por isso, estudar a trajetória do Palácio Monroe permite conhecer as imbricações históricas entre sociedade, cidade, arquitetura e (não) preservação, permitindo compreender as relações e os meios de idealização, produção, construção, circulação e recepção dessas obras aos moldes dos que vem sendo alertados e defendidos por Ulpiano Bezerra de Meneses, por exemplo (MENESES, 2003, p. 1996).

Essa tarefa é complexa, pois revela situações em que os limites disciplinares são tangenciados. Tratando-se de edificações, o campo da Arquitetura e do Urbanismo é, claramente, mobilizado, mas, por outro lado, por abordarmos edificações que não mais existem, forçosamente somos 
3. Consultar a respeito Milton Santos (1992) e Gerard Monier (2006). conduzidos a reflexões típicas do campo da Memória e da História, e, algumas vezes, até mesmo da Arqueologia Histórica. Imbricada entre esses campos disciplinares, ainda comparece a estrutura reflexiva da Filosofia e, também, da própria ideia de Psicologia Social, uma vez que a persistência de memórias, ressignificações e representações a posteriori parecem mesmo tocar dimensões arquetípicas suprageracionais.

Essas considerações mostram que as edificações não são meramente suportes de atividades ou abrigos. São, visivelmente, elementos simbólicos, capazes de servirem a materializações de discursos e de políticas; são espaços dotados de significados desde sua concepção até sua ocupação. São elementos discursivos, enfim. Assim, construir e demolir, embora pareçam neutros, desvinculados de tensões, pelo simples fato de se oporem, desvelam conflitos que permitem ao historiador questionamentos, como: "a que se deve uma construção?"; "quem a projetou?"; "quem idealizou sua demolição?"; "quem executou a demolição?"; "como reagiram os ocupantes à demolição?". Essa lista de perguntas já permite perceber que as edificações são, por essência, obra coletiva, que se inserem naquilo que diversos autores chamam de "produção social do espaço", atitude processual e polissêmica. ${ }^{3}$

Na análise do Palácio Monroe pode-se notar a presença intensa do corpus social, vinculando-se àquilo que o historiador francês Gerard Monier alinhavou senão como atitude metodológica, por certo, como preocupação básica do historiador: documentar a produção e a difusão de informação de que o edifícioevento é objeto, interrogando-se sobre sua extensão no espaço e no tempo - até onde, durante quanto tempo, como e por que se difunde a informação sobre o evento? Quem são os atores? Que contribuição durável isso traz à recepção? (MONIER, 2006, p. 15)

Como postula Monier, o "edifício evento" é entendido, na contemporaneidade, como aquele em que a massiva gama de informações midiáticas o envolve, decretando socialmente uma inserção compulsória no cotidiano urbano, sem, muitas vezes, conseguir se sustentar por qualidades ambientais, projetuais e espaciais no tempo e no espaço. Essa terminologia, como aponta Monier, é decorrente da atuação do setor imobiliário e de municipalidades imbuídas de um caráter propagandístico que transformam a produção espacial em alegoria de desenvolvimento, em uma coisificação sem impactos sociais, em um "evento", uma festividade vã. Contudo, contrapondo-se a essa "súbita inserção no espaço público" está a destruição de obras de arquitetura como também reveladora da existência de "edifícios-evento". $\bigcirc$ mesmo Monier nos esclarece que esse tipo de ocorrência pode ser denominado de "evento fortuito", de origem acidental ou decorrente de guerra, mas com força o suficiente para "determinar campanhas de opinião, no contexto de intensa mobilização patriótica", abarcando edifícios que no imaginário social nunca correriam o risco de desaparecimento, e que, por isso, foram deflagradores de lutas preservacionistas quando foram demolidos (MONIER, 2006, p. 14). 
Podemos ampliar essa recepção ao focarmos o papel da imprensa e do periodismo na "constituição/instituição dos modos de viver e pensar" urbanos (CRUZ, 2000), e, assim, paralelamente, sobre a recepção do patrimônio.

Heloisa de Faria Cruz e Maria do Rosário da Cunha Peixoto pontuam, com lucidez, um cuidado que os pesquisadores devotados aos estudos históricos devem ter ao incorporar as fontes emanadas da imprensa em seus trabalhos. Dizem as pesquisadoras que

os diversos materiais da imprensa, jornais, revistas, almanaques, panfletos, não existem para que os historiadores e demais cientistas sociais façam pesquisa. Transformar um jornal ou revista em fonte histórica é uma operação de escolha e seleção pelo historiador e que supõe seu tratamento teórico e metodológico. Trata-se de entender a imprensa como constitutiva do social, que detém uma historicidade e peculiaridades próprias, e requer ser trabalhada e compreendida como tal, desvendando, a cada momento, as relações imprensa/sociedade, e os movimentos de constituição e instituição que esta relação do social propõe. (CRUZ; PElXOTO, 2007, p. 2581

Pois bem. Esse alerta mostra que, embora as fontes "de periodismo" sejam autônomas em suas implicações, são, também, ótimos "termômetros" do ambiente social em que foram publicadas, levando-nos a perceber, além, os condicionantes que deflagraram pautas, argumentos e espaços nas páginas de notícias.

Ao abordar um tema complexo, como a demolição de edifícios, contido dentro do universo controverso da preservação, alguns caminhos são possíveis: primeiramente, compulsar os documentos oficiais exarados pelos órgãos preservacionistas (notificações, dossiês, processos de tombamento, recursos etc.); em segundo plano, a procura por testemunhas orais capazes de evocar e narrar acontecimentos e situações envolventes dos episódios em estudo; e, por fim, mas não menos importante, pesquisar o ambiente retratado pela imprensa a abordar tal temática.

Em tela, então, temos o Palácio Monroe, construído em 1904 para servir de pavilhão brasileiro na feira comemorativa da compra da Lovisiana, nos Estados Unidos (Figura 1), e remontado no Brasil, com poucas alterações, em 1906, no final da Avenida Central, principal elemento da Reforma Passos naqueles anos (Figura 2) (ATIQUE, 2013, p. 74-79). $\bigcirc$ estudo dessa edificação permite, pois, entender como os órgãos de preservação atuantes no território carioca lidaram com edifícios que, embora vinculados a discussões acadêmicas e eruditas sobre os valores arquitetônicos, acabaram sendo alvo de demandas pró-preservação de não especialistas, advindas, de certa forma, de grande ala da sociedade carioca nos anos 1970. Essa atitude pró-preservação, requisitada por "não especialistas", deflagrou a procura por aquilo que se convencionou chamar de "circuito social da obra", ou seja, o entendimento da idealização, da produção, da construção, da circulação e da recepção dessas arquiteturas como deflagradores de mecanismos de memória, que repercutem no meio social para além do imaginado pelo projetista. ${ }^{4}$
4. A esse respeito, ver os autores ligados à "Estética da Recepção", como Paul Valery, George Kluber e Hans Robert Jauss. 


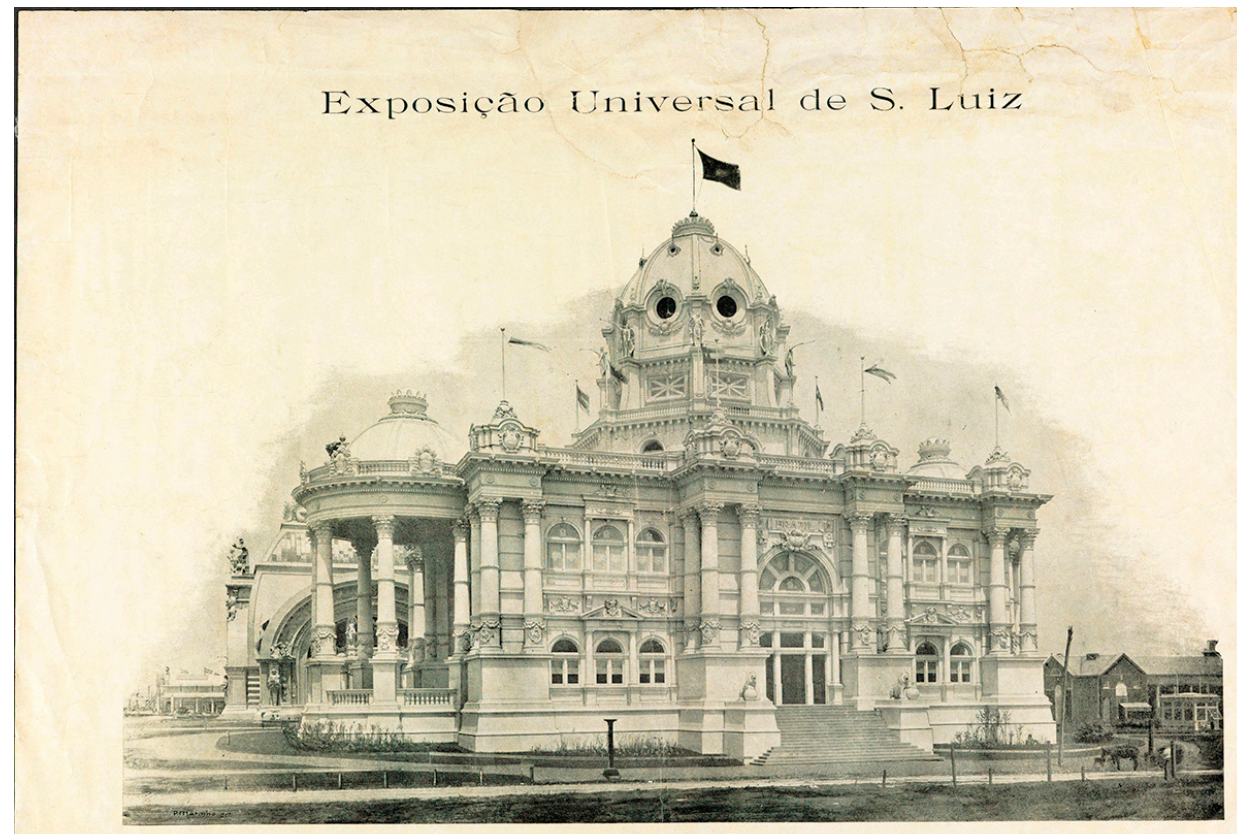

O Payinao do Brasil
Figura 1 - Imagem mostrando o Pavilhão Brasileiro construído na Feira Internacional de Saint Lovis, em 1904. Imagem de P. Marinho, Typographia de "A Editora", 1904. Fonte: Acervo Brasiliana Fotográfica da Biblioteca Nacional.

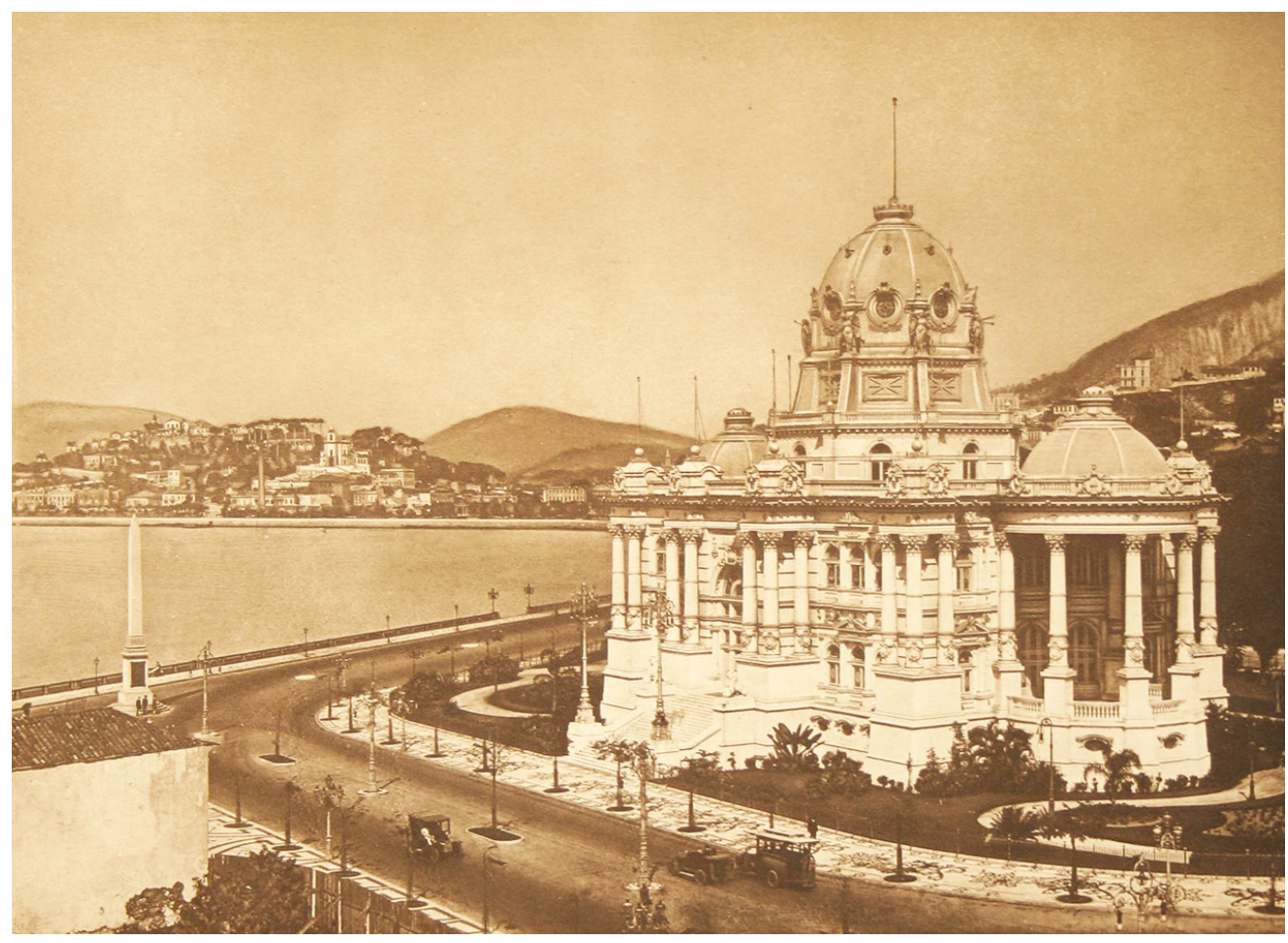

Figura 2 - Vista do Palácio Monroe recém-concluído, defronte à Baía de Guanabara. Fonte: Rovelly, 191? 
Essa análise levou-nos a entender tanto o percurso físico quanto o simbólico da edificação. Algo importante de ser frisado, também em seu caráter metodológico, é que a repercussão de uma edificação extrapola os limites de seu lote e os domínios de seu proprietário. No caso do Monroe, algumas considerações acerca da circulação de sua "imagem" e das suas representações se tornam importantes veículos para o entendimento de seu papel no ambiente carioca. Fotografado insistentemente ao longo do século XX, o Monroe, como edifício público, tornou-se cartão-postal, figurou em capas de livros, em seriados televisivos, em filmes, revistas de variedades e em jornais, além de ter sido pintado inúmeras vezes.

fato de ter sido sede da Câmara dos Deputados (1914-1922) e, durante maior tempo, do Senado (1925-1960) gerou uma circulação de seu nome em notícias e atos do legislativo pelo país, que redundou em sua associação com a antiga capital federal, tornando-o "conhecido" até mesmo por aqueles que nunca pisaram em solo carioca.

poder de atuação de elementos visuais sobre a memória tem, dessa forma, grande significação para a compreensão do patrimônio. Embora um edifício não seja apenas imagem, pois envolve uma dimensão que podemos chamar de "tectônica" (FREITAS, 201 2), as técnicas de reprodução de sua imagem ampliam o espectro de seu conhecimento social.

Dessa forma, as considerações de Alberto Goyena Soares sobre a fotografia ajudam a perceber como a sociedade lida com os edifícios, abrindo espaço para a discussão de sua recepção. Diz Goyena Soares que "a fotografia atua não tanto como instrumento de regresso ao passado, mas como forma de inserir o passado no presente, mantendo sempre vivas imagens de outras épocas de modo a que possam regressar voluntária ou involuntariamente à cena atual" (SOARES, 2009).

Aceitando-se a premissa de que a recepção do patrimônio pode se dar por outras entradas além daquela inerente à preservação do físico, da matéria, o Monroe pode ser considerado um dos mais exemplares objetos nessa linha. Dessa maneira, propusemo-nos a discutir as memórias a ele atreladas e as ressignificações que assumiu, muito embora tenha desaparecido.

Em suma: o desaparecimento de algo eleito pela sociedade como patrimônio provoca perda e desambientação social. ${ }^{5}$ Essa máxima expõe também razões obliteradas tradicionalmente na explicação dos movimentos sociais em derredor às políticas preservacionistas da década de 1970 no Rio de Janeiro.

Deflagração de "pautas" e polêmicas

A campanha pró-demolição do Palácio Monroe teve origem, paradoxalmente, em um documento que o considerava um bem a ser preservado. Redigido em 1972 por Paulo Santos (1904-1988) - arquiteto e historiador da arte e da arquitetura e conselheiro do Instituto do Patrimônio Histórico e Artístico
5. Segundo a célebre expressão de Eric Hobsbawn (1996, p.13). 
Nacional - Iphan -, o documento pretendia tombar o conjunto arquitetônico remanescente da abertura da Avenida Central, rebatizada, em 1912, como Avenida Rio Branco. Paulo Santos indicava a necessidade de tombamento de edifícios de diversas épocas, como a Biblioteca Nacional, o Theatro Municipal, a Câmara dos Vereadores, a antiga sede da Escola Nacional de Belas-Artes e alguns outros edifícios remanescentes na área conhecida como Cinelândia.

A demanda havia partido, naquele ano de 1972, do Clube de Engenharia do Rio de Janeiro em conjunto com o Instituto de Arquitetos do Brasil, seção Guanabara. Paulo Santos discorria, então, nitidamente imbuído dos preceitos da Carta de Veneza, de 1964, sobre a necessidade de tombamento de conjuntostestemunho de diversas épocas na Cinelândia. $O$ parecer surtiu efeito para além do esperado, sobretudo dentro do próprio Iphan. Lucio Costa, aposentado da Divisão de Estudos e Tombamento do órgão pouco tempo antes, dirigiu-se ao Conselho Consultivo rebatendo as considerações de seu colega, Paulo Santos. Costa, em texto nomeado de "Problema malposto", tergiversou contra a ideia de tombarem diversas obras arroladas, mas deteve-se com grande fôlego no combate à inclusão do Palácio Monroe nessa lista. A ideia de que o Monroe deveria desaparecer em prol do "desafogo urbano", expressão tão vaga quanto sedutora, tomou a imprensa, em especial as páginas do jornal $O$ Globo. A alegação de que os 5 mil metros quadrados ocupados pelo Monroe em meio a uma praça seriam um ganho real de qualidade urbanística para a cidade do Rio de Janeiro, lançada pelo jornal, foi repetidamente trazida pela mídia, atraindo opiniões de políticos, administradores e do grande público que, curiosamente, viu-se envolvido em uma campanha preservacionista. É essa ação da imprensa - mais especificamente de alguns editoriais, de cartas de leitores e de reportagens publicadas n' $O$ Globo nos anos 1970 - que é analisada, num primeiro momento, para que consigamos compreender uma suposta "vitória em prol da moralização com os gastos públicos", conforme defendia o periódico. Mas ressaltamos que estamos com os olhos voltados à compreensão da imprensa na formulação de uma dupla postura: a chancela demolidora e a recusa ao desaparecimento da edificação.

Recorrendo, mais uma vez, a Heloísa de Faria Cruz e Maria do Rosário da Cunha Peixoto, percebemos que entender a imprensa é levá-la a um processo de desnaturalização de sua atividade, inserindo-a numa moldura constitutiva do social (CRUZ; PEIXOTO, 2007, p. 258), que detém uma historicidade e peculiaridades próprias, além, claro, de doses ideológicas.

Esse alerta das autoras mostra que, embora as fontes "de periodismo" sejam autônomas em suas implicações, são, também, ótimas janelas do ambiente social em que foram publicadas, levando-nos a perceber, além, os condicionantes que deflagraram pautas, argumentos e espaços nas páginas de notícias. Estudos acerca da patrimonialização têm despertado, nos últimos anos, a compreensão da imprensa dentro da seara preservacionista. Podemos listar, por exemplo, o livro que compila os editoriais de Carlos Lemos, publicados na Folha de São Paulo entre 1972 e 2009 (LEMOS, 2013); a dissertação de mestrado de Felipe Crispim, que 
trata da patrimonialização da paisagem pelo Conselho de Defesa do Patrimônio Histórico Arqueológico, Artístico e Turístico (Condephaat) e realiza um diligente estudo das páginas d'O Estado de São Paulo visando prospectar a recepção das políticas de preservação (CRISPIM, 2014); a dissertação de mestrado de Luís Gustavo Pereira Ferreira sobre a introdução, em São Paulo, do conceito de patrimônio ambiental urbano e a criação do Conselho Municipal de Preservação do Patrimônio Histórico, Cultural e Ambiental da Cidade de São Paulo (Conpresp) (FERREIRA, 20 15); e o antológico livro de Marly Rodrigues acerca da história e das ações do Condephaat. Mesmo assim, ainda é pequena essa relação de estudos históricos que problematizem a ação da imprensa (RODRIGUES, 2000).

O estudo que realizamos permitiu verificar o papel, para com o destino do Palácio Monroe, do jornal O Globo, carro-chefe das Organizações homônimas. O Globo foi fundado em 1925 por Irineu Marinho, mas com seu falecimento semanas após a sua primeira veiculação, os negócios recaíram sobre Roberto Marinho, filho mais velho e criador do "império das comunicações" tão conhecido dos brasileiros ao longo do século XX. O Globo seguiu, em seus primeiros anos, a linha que já havia sido experimentada por Irineu Marinho no jornal A Noite, periódico do qual foi sócio de 1911 até 1925. Como aponta José Murilo de Carvalho, A Noite "foi atrás do leitor comum, adaptou a ele sua linguagem e temática, ampliou a presença de reportagens" (CARVALHO, 2012, p. 11). O Globo, contudo, foi se constituindo numa espécie de arauto não mais das classes populares, e, sim, dos setores médios e também de extratos da elite carioca. A importância d'O Globo foi crescente ao longo das décadas centrais do século XX, chegando a se tornar a principal referência em termos de debate políitico e cultural no Rio de Janeiro. ${ }^{6}$

Não por acaso, em 4 de julho de 1974, o arquiteto e professor da Faculdade de Arquitetura e Urbanismo da Universidade Federal do Rio de Janeiro, UFRJ, Wladimir Alves de Souza (1908-1994), declarou ao jornal em tela que "a demolição do Palácio Monroe possibilitaria à cidade ganhar uma área ajardinada, um complemento do Passeio Público, que ele considera[va] muito importante para - Rio" (O GLOBO, 1974a). Essa declaração do conhecido professor carioca não foi, contudo, evento isolado. Antes, deve ser lida como uma das primeiras "socializações" da polêmica até então restrita ao ambiente do Instituto do Patrimônio Histórico e Artístico Nacional.

Como vista, a campanha pró-demolição do Palácio Monroe teve origem, paradoxalmente, dentro do próprio Iphan, no documento, parecer-parte do Processo 860-T-72, da lavra de Paulo Santos. A ideia de que o Monroe deveria desaparecer em prol do "desafogo urbano", lançada por Costa e seguida por diversos membros do Conselho Consultivo do Iphan, tomou a imprensa, pouco a pouco, sendo a declaração de Alves de Souza a primeira, nesse sentido, verificada n'O Globo, e reproduzindo os mesmos argumentos encontrados no seio daquele instituto. Entretanto, tal argumentação lançada pelo jornal foi repetidamente trazida nas edições seguintes. No dia 6 de julho do mesmo ano, o jornal expunha a
6. Em específico, a atuação dessa mídia durante a década de 1970 carece, ainda, de maiores investigações, mas já podemos notar, mediante a pesquisa realizada, que o jornal gozava de grande prestígio perante $o$ governo militar, bem como das classes de funcionários públicos ainda radicados no Rio de Janeiro, que quinze anos atrás havia perdido a chancela de capital federal. 
7. Conferir O GLOBO, 1974c, para a íntegra da declaração de José Honório Rodrigues. essência da "campanha" que começaria a defender: "vazio de importância artística e modesto em importância histórica, o melhor destino que se pode dar hoje ao falso Palácio é demoli-lo" (O GLOBO, 1974b).

Analisando outras edições d'O Globo, notam-se outros artigos pródemolição. Consultado, um dos historiadores de maior renome no cenário nacional de então, José Honório Rodrigues, declarou que apoiava a ideia de demolição do Monroe, pois o único acontecimento histórico notável transcorrido ali "havia sido a III Conferência Pan-Americana", em 1906.7

Conferindo a seção de Cartas ao Leitor em diversas edições, consegue-se perceber como vai se configurando uma teia de relações ao redor do edifício, mostrando aspectos interessantes da vida urbana carioca. Como exemplos, podemos citar o trecho da carta do deputado Mario Saladini, filiado ao então MDB, que expressava uma concepção muito arraigada em parte da população das classes média e alta da cidade: "tombar o quê e por quê? [...] É preciso acabar com essa mania de tombamento de tudo o que é pardieiro da cidade" (O GLOBO, 1974d). Na linha oposta, outro leitor, João Guilherme Clarck, colocava-se em pleno diálogo com a declaração de Wladimir Alves de Souza: "pergunto ao Professor Wladimir Alves de Souza se sabe quantos monumentos e prédios da Belle Époque existem tombados e protegidos pelo mundo? [...] Por favor, ao invés de pregar a demolição do Monroe, lute por sua recuperação" (O GLOBO, 1974d).

Também na mesma edição, ainda é possível ler as declarações de um incerto P. Santos, que se coloca claramente ciente do discurso enviesado e contrário à permanência do Monroe. Diz, P. Santos que:

não se pode negar, mesmo não se gostando do prédio, que esse tipo de composição arquitetônica é peculiar à época em que foi construído, sendo, o edifício, portanto, representativo de um período. E também não se pode negar que o funcionamento do Senado no local durante tantos anos - e anos importantes na história do Legislativo do país - the confere importância histórica. (O GLOBO, 1974d)

Vê-se, então, que a possibilidade de demolir o edifício foi atraindo opiniões de políticos, administradores e do grande público, moldando o repúdio à ideia tecnocrática de gestão da cidade que vinha sendo praticada em solo carioca, com grande impacto, ao longo de todo o século XX.

Nesse sentido, a arquitetura "eclética" do Palácio Monroe parece ter ajudado a criar, também, uma celebração romântica acerca da cidade do Rio de Janeiro. Muitos leitores passaram a reivindicar a preservação do Palácio, por verem nele "lembranças do princípio do século, de época anterior às duas grandes Guerras Mundiais, e às enormes transformações por que o mundo desde então tem passado" (CARVALHO, 1974). Também escreviam leitores que expressavam uma espécie de "retórica da perda", uma vez que discordavam da demolição do Monroe "por ser representativo de uma época da arquitetura, época da qual restam poucos exemplares em nossa cidade" (SANTOS, 1974) 
Embora em pleno período militar, a "campanha pró-Monroe" alcançou grande envergadura, sobretudo em jornais concorrentes d' $O$ Globo, como o Jornal do Commercio, segundo declaração dada por Ubirajara Dettmar, antigo repórter fotográfico do periódico, em conversa informal, em 2010. Nesse sentido, é muito interessante perceber que, mesmo dentro do poder público, atitudes foram tomadas visando à permanência do edifício.

Missivas e intromissões

Convém mostrar que a efervescência da imprensa acerca da demolição foi o estopim da corrida dos Ministérios radicados no Rio, em busca da manutenção e ocupação do Monroe, "repositório de tradições", conforme palavras de José Alfredo Nunes de Azevedo (AZEVEDO apud AGUIAR, 1976, p. 208). As razões capazes de serem mobilizadas para essa corrida de ministérios podem ser encontradas numa sequência de ofícios arquivados no Iphan, que apontam a carência de espaços para as diversas pastas da União, sobretudo dos Ministérios da Fazenda e da Justiça em solo carioca (INSTITUTO DO PATRIMÔNIO HISTÓRICO E ARTÍSTICO NACIONAL, [s.d.]).

Valendo-se de informação publicada no Jornal do Brasil, em 29 de abril de 1975, Evandro Gueiros Leite, juiz federal, dirigiu-se ao ministro presidente do Conselho da Justiça Federal, Mario Ribeiro, solicitando informações acerca da mudança do Senado, sucursal Rio e, na sequência, requisitando o uso do edifício, uma vez que via, com essa possibilidade, a chance de sanar problemas de acomodação enfrentados pela Justiça Federal, no Rio. ${ }^{8}$ Em 29 de setembro de 1975, José Carlos Soares Freire, secretáriogeral do Ministério da Fazenda, em ofício endereçado ao ministro da pasta, opina a favor da cessão do Monroe à Justiça e recomendava que o senhor ministro se dirigisse ao presidente da República, Ernesto Geisel (1907-1996), para uma solução em definitivo, mas com especial endosso da preservação do Monroe. Em resposta ao ofício encaminhado por Mario Henrique Simonsen, em $1^{\circ}$ de outubro de 1975, ao presidente Geisel, Golbery do Couto e Silva, ministro-chefe do gabinete presidencial, esclareceu que cumpria "recomendações do Senhor Presidente da República no sentido da demolição do prédio e consequente transformação da área em logradouro público" (SILVA apud AGUIAR, 1976, p. 212).

Embora autores diversos apontem para um decreto datado de 11 de outubro de 1975, pelo qual Geisel autorizava a demolição do Monroe, pesquisas recentes mostram que esse decreto nunca foi, de fato, publicado (MACEDO, 2012). Mesmo assim, o ato oficial, advindo da pena do general Golbery do Couto e Silva, que produziu um ofício apenas, surtiu efeito de lei, - que levou o Palácio ao chão entre janeiro e junho de 1976. $\bigcirc$ jornal $O$ Globo comemorou a notícia:
8. Louis Aguiar também reproduziu tal missiva. Verificar Louis de Souza Aguiar (1976, p. 203). 
foi, portanto, vitoriosa, uma campanha deste jornal, que há muito se empenhava pelo desaparecimento do monstrengo arquitetônico [sic] da Cinelândia [...] Em seu lugar o Rio ganhará mais uma praça. Que essa boa notícia, que coincide como fim das obras de superfície do metrô na Cinelândia, seja mais um estímulo à remodelação de toda essa área, de presença tão marcante na história do Rio de Janeiro. $(\mathrm{O} \mathrm{GLOBO}, 1975)$

Sendo a cidade também um universo de pedras, o desaparecimento de edificações mostra que a memória é apenas uma das dimensões do campo do patrimônio, e que, como tal, fenece e não substitui a "experiência" urbana como deflagradora e constituinte da mesma. Essa "eleição", ou em outros termos, essa identificação pela sociedade de arquiteturas do passado, demonstra algo que se deseja ver instaurado nas práticas de preservação: a incorporação da sociedade local na defesa de um bem. Estranho é que, no caso que estamos analisando, a sociedade se manifestou por meio de abaixo-assinados e, em especial, pelas colunas de leitores de jornais. Manifestou-se, foi ouvida, mas não teve seu desejo acatado. Curioso, ainda, é que embora o veículo de imprensa condutor da campanha pró-demolição, O Globo, até tenha publicado cartas de leitores contrários ao desaparecimento do Palácio Monroe, apenas os "especialistas" foram ouvidos e tiveram suas opiniões publicadas com destaque no jornal, em entrevistas ou reportagens específicas, corroborando a campanha do desafogo urbano e da moralização política, aderidos às pedras e tijolos do Monroe como pátina.

Obviamente, o fato de estarmos tratando da década de 1970, período da ditadura militar e, mais especificamente, de um dos momentos anteriores à abertura política, a ideia de participação social não parece fazer parte da análise, mas ela estava ali, aflorando, sem dúvida alguma. Tanto que a organização de abaixo-assinados e a possibilidade de redação de missivas contrárias à demolição descortinam a superfície de um profundo reservatório analítico, ainda a ser mais explorado.

Também se faz importante mostrar que as inúmeras sociedades civis organizadas e os vários órgãos de classe que se manifestaram a favor da permanência do Monroe, como o Instituto de Arquitetos do Brasil (IAB) do estado da Guanabara, o Clube de Engenharia, a Associação dos Advogados, entre outros, também requisitaram o espaço para a ampliação de suas ações ou mesmo para a instalação de outras, em especial de caráter cultural, como uma possível sede para um Museu e Arquivo do Advogado (JORNAL DO BRASIL, 1975). Essas associações, embora sejam vistas como representativas de uma certa "tecnocracia" cultuada no país há décadas, cuja respeitabilidade e caráter decisórios eram ainda inegáveis nos anos 1970, mostram mais uma contradição reinante na sociedade de meados daquela década. Os bacharéis não se alinharam, via de regra, à editoria d' $O$ Globo, sendo poucos os profissionais que, de fato, emitiram opinião endossando a campanha do jornal.

Mas, mesmo assim, nem o lphan nem o governo federal cederam 0 espaço aos órgãos que o pleitearam. Ainda convém apontar que a discussão 
acerca da compreensão da demolição do Monroe permite afirmar que ela não foi pacífica e, muito menos, ignorada pela sociedade carioca. As cartas de lamento e as polêmicas levantadas perduram até a atualidade, revelando, por um lado, uma compreensão romântica do patrimônio, mas, como outra face da mesma moeda, uma sinalização de que as políticas públicas de preservação podem ser beneficiadas com as escutas atentas que podem vir das ruas, e também das páginas de jornal e das telas da web (Figura 3).
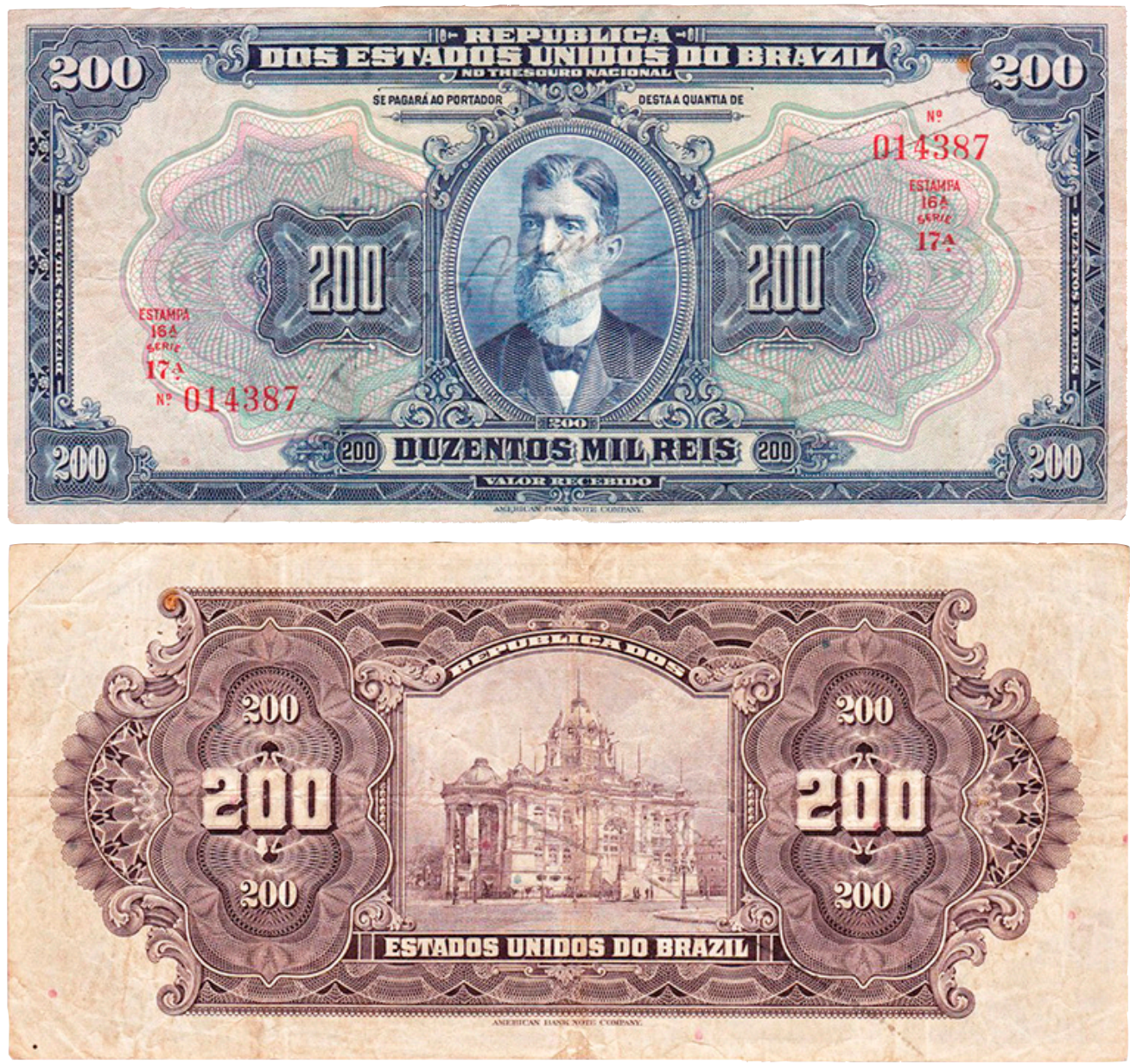

Figura 3 - Cédula de 200 mil-réis com o Palácio Monroe, que circulou entre a década de 1920 e meados da década de 1950. Fonte: acervo particular do autor.

Lamentos em tela

caso da demolição do Monroe persiste como uma espécie de trauma. Com o advento da internet, a situação de latência com o inconformismo da demolição foi revertida, tornando-se pauta corriqueira em sites, blogs e páginas com temática preservacionista ou mesmo de curiosidade pelo passado carioca. 
9. Na maioria dos buscadores da internet o uso das aspas (") ajuda a refinar a pesquisa para aquela expressão exata. A maneira mais fiel de se refinar ainda mais a busca é utilizando-se o sinal de agregação (+), quantas vezes se fizer necessário. Dessa maneira, a busca recairá sobre indexadores que tenham relação mais estreita com o que se deseja consultar, eliminando conflitos, que no caso do Palácio Monroe, recairiam, também, sobre a Doutrina Monroe e a atriz Marilyn Monroe, por exemplo.
Durante a pesquisa, foi possível perceber um recorrente lamento, que, inegavelmente, possui um tom "romântico", de idealização do passado, o qual já aparecia nas cartas das seções do leitor da década de 1970, mas que, na contemporaneidade, também se revestiu de estruturas argumentativas mais densas, reivindicadoras e, sem dúvida, preservacionistas. Passamos, então, a consultar diversos desses blogs "especializados" em discussões preservacionistas ou em coleta de imagens do Rio de Janeiro antigo, de forma a compreender as recorrências discursivas e as argumentações apresentadas. A maneira de se achegar a essas páginas da web foi curiosa. A partir de buscadores da internet, valendo-nos dos termos de busca "Palácio Monroe" + "Rio de Janeiro" + "blogs", 9 encontramos as páginas mais acessadas. Por meio delas, na seção de links úteis, navegamos por postagens semelhantes. Outro percurso também seguido foi, quando disponível, acessar as páginas que nos comentários apareciam como sugestões de ampliação da discussão ou mesmo de outras imagens. A interconectividade nesse universo digital é ampla, e a quantidade de informação, gigantesca. Dessa maneira, o filtro aplicado para obtenção do conteúdo que nos interessava foi, sempre, vinculação à representação, história, imagem e notícias sobre o Monroe, no Rio de Janeiro.

O blog Coisas da Arquitetura, em 21 de abril de 2010, por exemplo, efetuou uma postagem intitulada: "Palácio Monroe. Por que foi demolido?". O texto, extenso, e bem-cuidado na apresentação dos fatos, recebeu diversos comentários. Alguns merecem ser reproduzidos aqui. O leitor S.C.V., no dia 3 de agosto de 201 1, escreveu:

Palácio Monroe - $\bigcirc$ que podemos fazer para que as novas gerações o conheçam, para que a nação brasileira o dignifique, e para que não seja apagado da história do Brasil? E por que não tombá-lo [sic] agora? A Praça da República, em Niterói, foi destruída e em seu lugar foi construído um monstrengo inacabado. Mesmo assim foi tombada. Hoje a temos reconstruída no formato original. E por que não reconstruílo agora? Muitas edificações que foram destruídas na 2a Grande Guerra foram reconstruídas. E por que não resgatar a sua memória agora, em Audiência Pública? Colocaríamos o déspota louco e vingativo Ernesto Geisel e seus asseclas, Lúcio Costa, O Globo e o lphan, no banco dos réus. (PALÁCIO..., 2010)

texto expressa claramente uma mágoa, talvez uma demonstração mesmo de luto para com a demolição. Contudo, permite também verificar uma estrutura argumentativa recorrente na sociedade brasileira. Gostaríamos de chamar a atenção para algumas expressões reveladoras da necessidade de uma maior presença da formação acerca do universo preservacionista. $\bigcirc$ uso da palavra "resgate" é curioso. Complementado pela palavra "memória", então, demonstra que há uma crença de que existe uma única maneira de se achegar ao passado, e que "resgatar a memória" seria uma espécie de libertação de uma prisão imposta a algo imutável.

Também se faz necessário perceber a ideia de que a reconstrução é possível tecnicamente, viável economicamente, desejável eticamente e moralmente necessária. Entretanto, como tem mostrado a historiadora espanhola Ascensión Hernández-Martínez, o filósofo Walter Benjamin, em 1936, expunha que a cópia 
"anulava o caráter original da obra (o que Benjamin denominava aura)" (HERNÁNDEZMARTÍNEZ, 2007, p. 1 12, tradução nossa). Por isso, a autora julga que

a reconstrução de certas obras arquitetônicas na atualidade tem conseguido justamente o contrário: reforçá-la, posto que têm feito que certas obras que se conservam somente na memória coletiva através de documentos gráficos se materializaram, transcendendo o valor documental e histórico, para converter-se em mitos de um passado que se evoca para ocultar ou cobrir as desilusões que provoca o presente. (HERNÁNDEZ-MARTíNEZ, 2007, p. 112, tradução nossal

Essa ideia de reconstruir o Palácio Monroe, compartilhada até mesmo por César Maia, prefeito carioca no início dos anos 2000, parece ter surtido um efeito maior do que o imaginado. ${ }^{10}$ Alguns autores do campo da arquitetura e da história, como Daniel Abramson," "Fernando Atique (2016), Beatriz Kühl (2010) e Ascensión Hernández-Martínez (2007), já teceram considerações sobre isso, em linhas gerais, apontando para as "tentações" do simulacro, para a cópia, e para o suposto perigo de se dispender dinheiro público num "monumento" que não teria função a priori, e cuja forma não estaria resolvida, pois o problema da originalidade, o mito recorrente da repristinação levaria a um debate acerca "de que forma, e de que ano falaríamos": do pavilhão em Saint Louis, de 1904? Do edifício de 1906, no Rio? Do edifício adaptado ao Senado, em 1925? Ou do edifício de 1976, amplamente reformado?

Por fim, convém ainda abordar a ideia de tombamento presente no texto do leitor da web que estamos analisando. A ideia de que só se preserva mediante o tombamento ainda se apresenta como o único caminho perante a sociedade brasileira. Esse instrumento, cuja eficácia tem sido reavaliada na contemporaneidade, ainda não foi substituído no senso mais amplo, levando a considerações do quão importante se faz a ampliação da discussão sobre preservação no país.

O blog Alma Carioca, em reportagem publicada há aproximadamente dez anos sobre o desaparecimento do Monroe, também recebeu de leitores apreciações. A.C.M. escreveu que "a demolição do Palácio Monroe no Rio de Janeiro é a prova incontestável de que o Brasil é um país que não dá a mínima importância à sua história!" (PALÁCIO..., 2013).

Mais opiniões expressando lamento e repúdio pelo acontecido são verificadas no blog Histórias do Rio. Ali, no post intitulado "Palácio Monroe, um rasgo na nossa memória", a abordagem sobre a construção, a ocupação pelo Senado e a demolição "traumática" são retomadas. Comentando, o leitor $M$ expressou tratar-se

de um imensurável crime de "lesa-pátria" dos tempos da ditadura! Totalmente injustificável, gratuito e dantesco, deixando a todos perplexos pela bestialidade de tal ato. Tão ou mais belo que o teatro municipal, pelo menos externamente, seria o mesmo que a derrubada deste, que graças ao Bom Deus, também não foi junto... Lamento não tê-lo [sic] conhecido pessoalmente, adentrado em seus salões, admirado sua fachada, enfim, hoje teríamos no centro do RJ, um dos palácios mais bonitos do mundo, servindo de um espaço relevante ao prazer de todos nós. (PALÁCIO..., 2012)
10. Faz-se alusão à controversa proposta feita pelo antigo prefeito do Rio de Janeiro, César Maia, que propôs a reconstrução do Palácio Monroe, em seu antigo local. A respeito, ver Cecília Rodrigues dos Santos (2004)

11. Sobre esse autor, consultar, em especial, Daniel M. Abramson (2015; 1999, p. 78-83). . 
12. Sobre Lucio Costa e a polêmica envolvendo o Monroe, recomendo a leitura de Santos (2004). O protagonismo de Costa nesse episódio tem muito a ver com sua interpretação estética. Defensor do modernismo, requisitante para si próprio de uma característica quase sobrenatural na transformação de sua prática de arquiteto que riscava edifícios "em estilos" para o modernismo - não relativizemos a expressão "conversão ao modernismo" por ele cunhada -, Costa desautorizou, diversas vezes, o tombamento de edificações que não comungassem com a linha evolutiva da arquitetura brasileira que, teleologicamente, redundava na Arquitetura Moderna. Outras vezes, contudo, chega a apontar características importantes de uma edificação por conta do uso que possuiu ou mesmo de seu idealizador, mas não as chancela para tombamento pelo Iphan, reputando responsabilidade aos órgãos estaduais e/ou municipais que surgiam no país, como fez com relação ao Solar Monjope, também demolido na mesma época no Rio. A esse respeito, consultar Fernando Atique (2016).
Esse comentário apresenta a ideia que ficou recorrente entre a opinião pública: a de que a ditadura militar tinha uma agenda oculta com relação ao edifício do antigo Senado. Mas, percebe-se, também, a defesa da tese de que o Monroe era uma arquitetura espetacular, destacada dentre suas congêneres, o que nos parece uma argumentação que se lançou durante a contracampanha de fundo preservacionista da década de 1970, contrariando as opiniões da imprensa e da tecnocracia que apelidaram o edifício de "monstrengo arquitetônico".

fórum virtual Skyscrapercity também possui uma postagem atinente à demolição do Monroe. Ali, comentários acerca do desaparecimento da edificação se fazem presentes. Um comentário, em particular, reúne duas informações interessantes acerca da circulação da imagem do Monroe. $\bigcirc$ leitor P. postou em 8 de julho de 2005:

Este prédio fez parte da minha infância, eu me lembro de que a minha mãe tinha um quadro grande com uma foto antiga dele na parede da sala, e que sempre me despertou curiosidade. Foi uma pena terem acabado com ele, ainda por cima, nas circunstâncias que foi e depois de tudo o que foi feito pelo Metrô para evitar que ele [viesse] abaixo.... É mesmo inaceitável que um presidente da República por pura birra deite abaixo um patrimônio da cidade, e que um arquiteto respeitado seja favorável a isso. (SKYSCRAPERCITY.COM, 2005)

A primeira diz respeito ao fato de que residências particulares, provavelmente sem nenhuma ligação com o universo da arquitetura ou mesmo do Senado Federal, tivessem um quadro com representação do Monroe. Está colocada aí, mais uma vez, a dimensão insondável que a cidade e seus artefatos arquitetônicos alcançam pela reprodução da imagem de edifícios implantados em locais de grande circulação, com arquitetura notável, com função pública e em eixos de visibilidade urbana explorados pelo turismo, como era o caso do Monroe.

Em segundo lugar, a recorrente "demonização" de Geisel e Lucio Costa aparecem. Essa recorrência na culpabilização desses personagens nos mostra o quanto a história precisa ser analisada em suas múltiplas dimensões. É inegável a participação de Costa no processo, repudiando a inserção do Monroe dentre os remanescentes da Avenida Central, mas seu papel foi secundário se comparado à deflagração da "campanha" que $\bigcirc$ Globo empreendeu. E, até o momento, nenhuma vinculação entre $\bigcirc$ Globo e Costa foi efetivamente descoberta. Todavia, a sociedade tem se mostrado, como aponta o leitor citado, decepcionada com o aval de "um arquiteto respeitado" ao fenômeno da demolição de um bem que foi assimilado afetivamente, mesmo que apenas por hipertexto, em tempos de internet. ${ }^{12}$

Em outro caso, o blog Foi um Rio que Passou realizou algumas postagens com fotografias alusivas ao Monroe. Uma delas, datada de 30 de novembro de 2009, intitulada "Monroe, final dos anos 60", mostrou opiniões um pouco divergentes das que até agora alinhavamos. Um leitor, R.N. escreveu:

eu continuo achando que as emoções que o Monroe desperta são, pura e simplesmente, pelo fato dele ter sido demolido. Como as pessoas que viram "mitos" depois que morrem. Se 
ele estivesse de pé seria apenas mais um palácio em volta da Cinelândia, talvez até incomodando por estar "no meio do caminho". (NETTO, 2009)

Esse comentário, de certa forma, controverso ao ambiente de lamúria reinante "nas telas" pela perda do Monroe, é interessante, pois permite avaliar também quem é o público que participa dos fóruns virtuais. Goyenna Soares aponta, comentando o trabalho de colecionadores de imagens do Rio Antigo, analisadas por jornalistas especializados em cultura, que

estas matérias reproduzem uma determinada lógica ou visão do patrimônio. Privando seus leitores de um "de onde, afinal, vem esse interesse pelo colecionamento [sic] dessas imagens em específico?", nada esclarecem a respeito daquela que François Hartog denominou "crise do tempo". Sem dúvida, parece-me que grande parte do êxito destas coleções, medido ao menos sob a ótica do alto número de acessos a estes sites, encontra sua razão de ser na ampla exposição e, digamos, treinamento, de uma sociedade através de cartilhas e políticas públicas que refletem esta modalidade contemporânea de compreensão do patrimônio. [...] Quando os confrades divulgam mediante fotografias, imagens daquilo que não existe mais, ou daquilo que não mais existirá no futuro, respondem certamente a esta lógica. Se, contudo, um regime de historicidade presentista com sua modalidade patrimonial ajuda talvez a explicar o sucesso quantitativo na recepção destas coleções, não creio que dê conta ou encerre outras particularidades centrais a estas exposições.[...] Se é verdade que a transitoriedade dos elementos e formas de vida cotidiana aparecem em suas legendas como um aspecto central, este projeto museográfico também é, como vimos, um que pretende erguer uma cidade paralela onde visitantes possam finalmente habitar as exposições. (SOARES, 2009, p. 162-163)

Essa análise vem ao encontro das preocupações que este texto tem, que são as de aferir até que ponto todo o movimento midiático garante, de fato, modificações nas políticas preservacionistas. Também nos leva a ponderar acerca do destino que essas "casas virtuais", localizadas em hipermídia, despertam nos leitores. Transcrevemos, então, postagem do blog Mundo Gump sobre a polêmica da reconstrução do Monroe, suscitada anos atrás. ${ }^{13}$ Diz o blog que

Quando era Prefeito do Rio, o César Maia propôs reconstruir o palácio. Alguns foram contra, outros foram a favor. Eu acho que o César Maia - mentor político daquele elefante branco, a Cidade da Música, - que não está realmente pronto até hoje, meteu apenas mais um factoide no povo. Um entre dezenas de outros. Pessoalmente, eu penso que gastar dinheiro público nisso talvez não seja uma prioridade realmente. Sobretudo quando pessoas pobres não têm onde morar, não tem comida, escola, hospital e o cacete a quatro que o nosso imposto deveria servir para pagar, mas vai direto para aumentos "aloprados" dos salários dos próprios políticos. Penso que o Palácio Monroe, caso fosse realmente cogitada sua ressurreição, deveria ser reerguido pela iniciativa privada. A começar com as organizações Globo, que foram também diretamente culpadas pela destruição do primeiro edifício brasileiro premiado internacionalmente. $\bigcirc$ palácio era todo numerado. Me pergunto: por que não seria possível criar um movimento para que as pessoas comprassem as pedras do palácio? Imagina, tipo uma vaquinha gigante. A reconstrução poderia ser parecida com aquela ideia do moleque que vendeu um milhão de pixels a um dólar cada. Fulano compra uma janela, Beltrano compra uma colu-
13. Um jornal de Alagoas, pertencente às organizações Globo, noticiou a intenção de Maia:

O PREFEITO CESAR MAIA vai reconstruir o Palácio Monroe, no Passeio Público, que foi demolido em meados dos anos 70 para a construção do metrô. O novo prédio será, na parte externa, uma cópia exata do antigo, que foi erguido para sediar a terceira Conferência Pan-americana e depois sede do Senado, até a mudança da capital federal para Brasília. Aliás, a empresa que está construindo o estacionamento subterrâneo, na Cinelândia, descobriu nas escavações, a cinco metros de profundidade, uma caixa metálica com a ata de lançamento do prédio - datado de 15 de novembro de 1905 , com a assinatura do ex-presidente Rodrigues Alves e recortes de jornais da época anexados. Vai doá-los à Biblioteca Nacional. (GAZETAWEB, 2015) 
14. Em 2003, por fim, inaugurou-se o estacionamento que permeou as polêmicas acerca da demolição do Monroe, nos anos 1970. na, o Eike [Batisła] compra a cúpula e assim vamos refazendo o estrago. Será que é possível encontrar a planta original do edifício? Imagina o quão gratificante poderia ser olhar para o prédio pronto e pensar: "Eu ajudei a reconstruir este palácio". E quem sabe a partir deste gesto não surgisse no coração das pessoas um desejo por reconstruir, recuperar e reativar áreas destruídas, abandonadas e empobrecidas da cidade. (DAVID, 2010)

Há uma necessidade de experimentar o espaço ou a reconstrução se torna uma espécie de vingança? $\bigcirc$ texto acima, ao evocar a possibilidade de colaboração para a reconstrução, parece esquecer-se de que um edifício está em conexão com o território, com uma área. Onde seria refeito o Monroe? As relações que a suposta obra reconstruída guardaria com o ambiente seriam as mesmas que teve outrora? Hernández-Martínez comenta isso ao abordar o caso das réplicas célebres de edifícios do Movimento Moderno de Arquitetura, como o Pavilhão Alemão, de Mies van der Rohe, erigido em 1929, em Barcelona, refeito no mesmo sítio, na década de 1990, e o Pavilhão Le Sprit Nouveau, de Le Corbusier, reconstruído em Bolonha, em 1977:

Não obstante a falta de conexão entre a cópia e o território onde se insere, já que em alguns exemplos se trata de obras transplantadas de seu lugar de origem, se converte em um obstáculo insalvável, já que este conhecimento não chega a produzir-se ao não existir uma relação histórica real entre a arquitetura e o território, o lugar onde se encontra, e, portanto, os cidadãos que o habitam, que não a sentem como sua, senão como um artefato estranho de que não sabem muito bem, nem época, nem autor. Esta situação acaba conduzindo ao abandono e à inutilidade do "clone arquitetônico" (HERNÁNDEZ-MARTíNEZ, 2007, p. 1 17, tradução nossa)

Alguns críticos pró-reconstrução poderiam argumentar que o palácio seria refeito na mesma cidade em que existiv e no "mesmo lugar", não havendo, assim, relação entre desambientação e clonagem, como apontado por Hernández-Martínez. Todavia, parece pueril tal sustentação, uma vez que, passados exatos quarenta anos da demolição do Palácio Monroe, a área em que ele esteve não é mais a mesma. Em seu subsolo existe um edifício garagem de múltiplos andares, ${ }^{14}$ que teria de ser retirado para que tivéssemos o porão do Monroe implantado. Se não puséssemos o porão, baseando-nos apenas na imagem vista a partir do nível da rua, então não poderemos falar de reconstrução, mas de um simulacro de edifício, o qual, igualmente, poderia ser construído com outros materiais, mais contemporâneos, abrindo sendas para a reintrodução de pensamentos leducianos.

Para além desse fato, a área recebeu um chafariz que também existia em outra área da cidade, originalmente. Maior "atração da área", o chafariz, com mais de 10 metros de altura, foi instalado bem ao centro do lugar ocupado outrora pelo Monroe. Toda em ferro fundido, a peça, datada de 1861, é obra do artista Lovis Sauvageau (1822-1885). Comprada pelo imperador Pedro II, que a conheceu em Viena, em 1878, foi fabricada na célebre casa francesa Societé Anonyme des HautsFourneaux \& Fonderies du Val d'Osne. No Rio, foi instalada, primeiramente, no 
antigo Largo do Paço (atual Praça XV), de lá seguiu para a Praça da Bandeira e, a pedido de Geisel, foi levada para a atual Praça Mahatma Gandhi, topônimo escolhido para batizar a antiga área ocupada pelo Monroe (Figura 4).

Afora o fato de que a avenida Rio Branco sofreu intervenções diversas no entorno do Monroe, como a inserção do projeto RioCidade, na gestão do próprio César Maia, que refez calçamento, instalou mobiliário urbano e remanejou o trânsito. Essa última questão, inclusive, também provocou alteração na paisagem da Cinelândia nos últimos anos, pois a instalação do Veículo Leve sobre Trilhos VLT - que passa pela área inseriu novos condicionantes de leitura do espaço. Alguns caminhos, entretanto, que se aproximam da produção memorial, têm sido vistos internacionalmente. Visando aplacar as perdas de edifícios consagrados pela população, a reconstrução virtual tem aflorado. Por meio de maquetes eletrônicas, edificações têm aparecido para fins diversos, desde cenários virtuais para filmes e seriados, até visitas virtuais de instituições com função patrimonial.

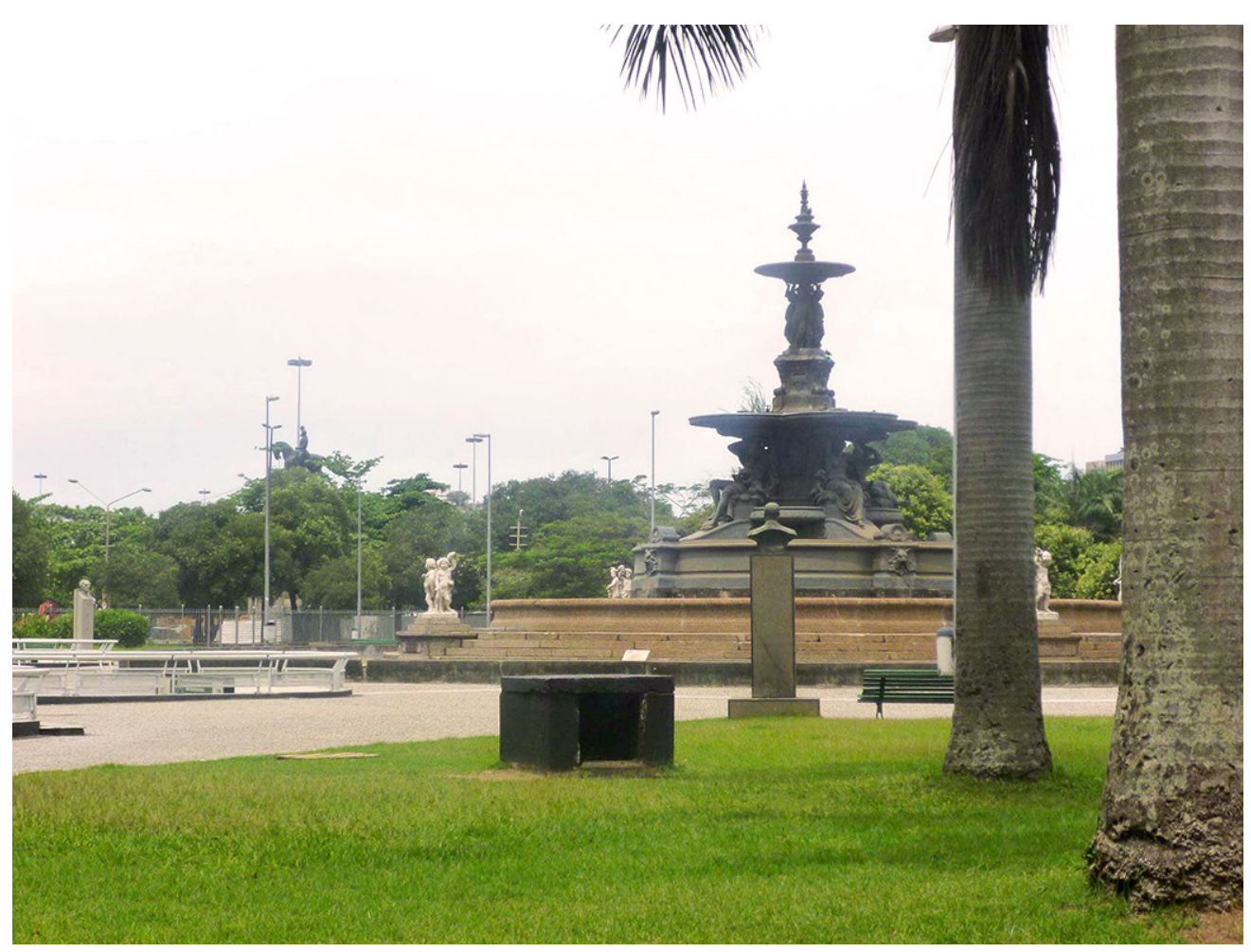

Figura 4 - aspectos recentes da Praça Mahatma Gandhi e do chafariz do Monroe. Foto: Renata Geraissati, 2015.

Recentemente, o jornal $\bigcirc$ Globo produziu um documentário virtual sobre - Monroe. Denominado de "Especial Monroe", e disponibilizado on-line, é, até o presente momento, a melhor maneira de se acessar, pavimento por pavimento, a edificação, em meio digital. Também traz, numa espécie de linha do tempo, todas 
15. Ver, a esse respeito, Harry Skrdla (2006). as etapas ligadas à antiga sede do Senado. Curiosamente, a manchete da página começa por apagar, deliberadamente, a participação do jornal no destino final do Monroe. Na tela inicial lê-se: "MONROE [sic]: O palácio que foi símbolo da República e derrubado pelos militares ainda vive no imaginário dos cariocas. Conheça um pouco mais a história do Monroe." (MONROE, [s.d.]).

Clonado ou não, compreendido ou desmerecido, podemos ver como a pauta "Monroe" tem sido presente na imprensa desde sua idealização, em princípio do século XX. Hoje, especificamente, a área outrora ocupada pelo Palácio Monroe acabou não se transformando na continuação do Passeio Público, muito menos em área verde, como diziam os adeptos à demolição. Ela é território sem grandes qualificações espaciais, já que, apesar de gramado, é também gradeado, com poucos portões. A Praça Mahatma Gandhi possui uma estátua em bronze de grande dimensão do pacifista indiano, feita pelo artista indiano Sankho Chanduri, em 1949. Apesar de simbólica, a imagem de paz não parece ter se coadunado à área, uma vez que toda gradeada não se transformou em lugar de convívio, uma característica que antagoniza com a vida urbana, em logradouros, tipicamente carioca.

\section{Considerações finais}

Enfim: de que maneira é possível uma história da não preservação? Esse questionamento foi, sem dúvida, o mote deste artigo. Se, no Brasil, nas últimas duas décadas tem sido possível verificar uma proliferação de estudos dedicados à seara preservacionista, ainda não temos, com grande ênfase, reflexões sobre o patrimônio que se esvaiu. Um primeiro ajuizamento a esse respeito poderia indicar que se certas obras desapareceram certamente pouco elas representavam dentro do "sistema cultural urbano". Entretanto, como explicar, então, a recorrência com que certas edificações desaparecidas de nossas cidades ressurgem em textos acadêmicos, blogs, revistas e artigos de jornais? Haveria, nessa persistência, alguma indicação de fantasmagoria arquitetônica? ${ }^{15} \mathrm{Ou}$ seria, por outro lado, um índice à maneira ginzburguiniana, que permite uma leitura de que as estruturas urbanas e os cidadãos ressentem-se dos desmantelamentos memoriais, físicos e simbólicos derivados das demolições que atingiram o ambiente urbano?

Antônio Augusto Arantes, aponta algo importante neste sentido:

o conhecimento dos processos sociais de apropriação da natureza, espaços ou edificações é fundamental para o norteamento das políticas de preservação. É a partir desses processos, em seus aspectos simbólicos e práticos, que elas podem contribuir para o fortalecimento da cidadania, pois é nos lugares apropriados ao espaço urbano pela vida cotidiana que brotam, florescem e frutificam as raízes do pertencimento. (ARANTES, 2006, p. 57)

Esperamos ter deixado claro que entender as razões que levaram edifícios célebres em suas épocas, tanto no meio intelectual ou técnico, quanto perante a sociedade do Rio de Janeiro, ao desaparecimento é um problema do campo histórico, porque, como pontua Monier, "cabe à aproximação histórica julgar se o valor patrimonial corresponde 
à força do evento" (MONIER, 2006, p. 17). Ou seja, historiando os processos de destruição de edifícios, consegue-se entender como socialmente os mesmos foram sendo colocados no "espaço público", ou, em outras palavras, como se teceu seu "circuito social", podendo-se, dessa maneira, compreender tanto as manifestações sociais contrárias às demolições, quanto certos lamentos historiográficos decorrentes da supressão da relação obra-lugar, mas, também, algumas sugestões de reconstrução dos mesmos, vindas à tona nos últimos anos. ${ }^{16}$ Obviamente, por meio deste procedimento, comungamos com Arantes o pensamento acerca daquilo que está no âmago do bem patrimonial: "a tensão que se forma entre os sentidos enraizados nas práticas dos grupos sociais que os detêm nos contextos de origem, e os que são atribuídos pelas agências institucionais" (ARANTES, 2006, p. 56). Patrimônio é, assim, uma seara em que convivem instâncias do poder público e o próprio público, que via de regra se oporão, até negociarem uma convergência, que poderá ter duração longeva ou breve. Não há como prever. Por isso, a análise em perspectiva histórica traz informação não para evitar supostos "reaparecimentos", mas, sim, para ampliar o repertório analítico acerca da dimensão urbana do patrimônio que se esvaiu.

Confirmando que a arquitetura pode ser analisada por meio de documentos diversos, como os hipertextos, e os depositórios digitais, abrimos uma possibilidade de análise que é rica e muito próxima de uma história social. Ao verificarmos como edificações foram recebidas, ou, em outras palavras, como edifícios agiram sobre as estruturas urbanas em termos formais, mas também emocionais, memoriais, artísticos, estamos permitindo a apreensão da arquitetura como obra que extrapola os limites operacionais. Metodologicamente, quando realizamos a ponte entre a análise do campo interno da arquitetura e suas importantes considerações sobre composição, forma, materialidade, proporção, citação e crítica, agregamos uma dimensão que é a apropriação.

Este artigo, ao perscrutar como as pessoas atribuem características emocionais, sentimentais, documentais e políticas aos edifícios, procurou mostrar como a história social a partir do periodismo pode auxiliar o desenvolvimento da arquitetura em alguns aspectos. Primeiramente, em tentar assimilar na concepção espacial características que são recorrentes no discurso compartilhado na internet sobre as boas qualidades de uma obra de arquitetura. Em segundo lugar, aumenta a seara de estudos da arquitetura para a compreensão dos meandros preservacionistas. Neste artigo, pontuamos que as políticas de preservação devem associar a preocupação com o circuito social da obra arquitetônica, estudando-a como forma de apoiar-se mais solidamente no âmago das relações sociais construídas ao redor dos edifícios, e não apenas nas teorias composicionais, posturas estéticas e perseguições ideológicas, em chave positiva ou negativa.

Com isso, analisar o percurso da mídia sobre o Palácio Monroe, das páginas impressas, aos blogs, sites e fóruns virtuais, nos permitiu perceber que a sociedade, mesmo "filtrada" pelos editores, manifestou-se em defesa daquela edificação. Isto só nos leva a enfatizar: a preservação é problema social, em especial, ao enfocar arquiteturas, pois não existe espaço que não tenha sido pensado para uso pelo ser humano.
16. Faz-se alusão à controversa proposta feita pelo antigo prefeito do Rio de Janeiro, César Maia, que propôs a reconstrução do Palácio Monroe, em seu antigo local. A respeito, ver Cecília Rodrigues dos SANTOS (2004). 


\section{REFERÊNCIAS}

ABRAMSON, Daniel M. Architectures of obsolescence: lessons for History. In: TISCHLEDER, Babette B.; WASSERMAN, S. Cultures of Obsolescence: history, materiality, and the digital age. New York: Palgrave Macmillan, 2015.

Make History, not memory. Harvard Design Magazine. Special issue on "Constructions of Memory". Cambdrige: Fall, 1999. p. 78-83.

ABREU, Maurício de. Evolução urbana do Rio de Janeiro. 3. ed. Rio de Janeiro: IPP, 1999.

AGUIAR, Louis de Souza. Palácio Monroe: da glória ao opróbrio. Rio de Janeiro: edição do autor, 1976.

ALLUCCI, Renata Rendelucci. A reconstrução da Capela das Mercês em São Luiz do Paraitinga. Urbana: Revista do Centro Interdisciplinar de Estudos sobre a Cidade, Campinas: IFCHUNICAMO, v. 6, n. 2 [9], 2014.

AMORIM, Luiz Manoel do Eirado. Obituário Arquitetônico: Pernambuco modernista. Recife: Funcultura; Instituto Delgim Amorim; UFPE, 2007.

ANDRADE, Antonio Luiz Dias de. O nariz torcido de Lúcio Costa. Revista Sinopses, São Paulo, n. 18 , p. $5-17$, jun. 1992 .

ANDRADE, Mário de. Anteprojeto do Patrimônio. In: CAVALCANTI, Lauro (Org.). Modernistas na Repartição. Rio de Janeiro: Editora da UFRJ; Paço Imperial; Tempo Brasileiro, 1993. p.39-56.

ARANTES, Antonio Augusto. O Patrimônio Cultural e seus usos nas cidades contemporâneas In: MORI, Vitor Hugo et al. Patrimônio: atualizando o debate. São Paulo: 9o SR/ Iphan, 2006. p.54-58.

ATIQUE, Fernando. De "Casa Manifesto" a "Espaço de Desafetos": os impactos culturais, políticos e urbanos verificados na trajetória do Solar Monjope (Rio, anos 20 - anos 70). Revista Estudos Históricos, Rio de Janeiro, v. 29, n. 57, p. 215-234, abr. 2016. Disponível em: <http:// bibliotecadigital.fgv.br/ojs/index.php/reh/article/view/59057>. Acesso em: 7 jul. 2016.

. O edifício imigrante. Revista de História da Biblioteca Nacional, Rio de Janeiro: FBN, v. 8, p. 74-79, 2013.

A invenção de uma cidade "histórica": O Parque Nacional da Independência dos EUA e as ações de Edmund Bacon, Robert Venturi e Penelope Batcheler. In: ARQUIMEMÓRIA - ENCONTRO INTERNACIONAL SOBRE PRESERVAÇÃO DO PATRIMÔNIO EDIFICADO, 4., Salvador, 2013. Anais... Salvador: IAB; UFBA, 2013.

Memória moderna: a trajetória do Edifício Esther. 2. ed. São Carlos: RiMa, 2013.

Operações no espaço, operações na memória: uma análise do Welcome Park, de Venturi, Scott-Brown \& Rauch, na Filadélfia. Arq.urb, n.13, p.59-76, jan.-jun. 2015. 
BENCHIMOL, Jaime Larry. Pereira Passos: Haussmann tropical. Rio de Janeiro: Prefeitura da Cidade do Rio de Janeiro, 1990.

BENJAMIN, Walter. Obras escolhidas: magia e técnica, arte e política. São Paulo: Brasiliense, 2008.

BLOG do Marcílio.com. Disponível em: <www.marcillio.com>. Acessos diversos.

BRASIL. Decreto-lei n. 25, de 30 de novembro de 1937. In: INSTITUTO DO PATRIMÔNIO HISTÓRICO E ARTÍSTICO NACIONAL. Coletânea de Leis sobre Preservação do Patrimônio. Rio de Janeiro: Iphan, 2006.

BRASILIANA Fotográfica. Disponível em: <http://brasilianafotografica.bn.br/brasiliana/> . Acesso em: 12 ago. 2016.

CARVALHO, Carmen. [Carta] 22 jul. 1974 [para] O GLOBO, Rio de Janeiro.

CARVALHO, Clara Cristina Valentin Anaya de. Os setores médios e a urbanização de São Paulo: Vila Mariana 1890 a 1914. 2015. Dissertação (Mestrado) - Escola de Filosofia, Letras e Ciências Humanas, Universidade Federal de São Paulo, São Paulo, 2015.

CARVAlHO, José Murilo de. Prefácio. In: CARVALHO, Maria Alice Rezende de. Irineu Marinho: imprensa e cidade. Rio de Janeiro: Globo Livros, 2012.

CASTRO, Ramiro Berbert de. Histórico e descripção dos edifícios da Cadeia Velha, Palácio Monroe e Bibliotheca Nacional. Rio de Janeiro: Empreza Brasil Editora, 1926. (Separata do Livro do Centenário da Câmara dos Deputados).

CAVALCANTI, Lauro. Modernistas na Repartição. Rio de Janeiro: Editora da UFRJ; Paço Imperial; Tempo Brasileiro, 1993.

(Org.). Moderno e brasileiro: a história de uma nova linguagem na arquitetura (19301960). Rio de Janeiro: Zahar, 2006.

COSTA, Lucio. Registro de uma vivência. São Paulo: Empresa das Artes, 1995.

CRISPIM, Felipe Bueno. Entre a Geografia e o Patrimônio. Estudos das ações de preservação das paisagens paulistas pelo CONDEPHAAT (1969-1989). 2014. Dissertação (Mestrado) - Escola de Filosofia, Letras e Ciências Humanas, Universidade Federal de São Paulo, São Paulo, 2014.

CRUZ, Heloísa de Faria. São Paulo em papel e tinta: periodismo e vida urbana, 1890-1915. São Paulo: Edusc; Imprensa Oficial; Arquivo do Estado, 2000.

; Maria do Rosário da Cunha Peixoto. Na Oficina do Historiador: conversas sobre história e imprensa. Projeto História, São Paulo, n. 35, jul.-dez. 2007.

DAVID, Philipe Kling. A volta do Palácio Monroe. Mundo Gump, 30 dez. 2010. Disponível em: <http://www.mundogump.com.br/a-volta-do-palacio-monroe/>. Acesso em: 20 jun 2015.

DECOURT, André. Favela da Praia do Pinto, vista da Pedra do Baiano - circa 1938. Foi um Rio que passou em minha vida, 9 maio 2012. Disponível em: <www.rioquepassou.com.br/2012/05/09/ favela-da-praia-do-pinto-visto-da-pedra-do-baiano-circa-1938/>. Acesso em: 20 nov. 2015. 
FERREIRA, Luís Gustavo Pereira. Emoldurando o cartão-postal através do qual se conbece São Paulo: poder, conflito e hegemonia no tombamento do Vale do Anhangabaú (1990-2000). 2015. Dissertação (Mestrado) - Escola de Filosofia, Letras e Ciências Humanas, Universidade Federal de São Paulo, São Paulo, 2015.

FOI um Rio que passou. Disponível em: <www.rioquepassou.com.br>. Acessos diversos.

FREITAS, Maria Luiza de. Interstícios históricos: projeto de arquitetura e urbanismo com ênfase em tecnologia construtiva. In: REZENDO, Marco Antônio Penido de (Org.). Tecnologia do ambiente construído e interdisciplinaridade. Belo Horizonte: Instituto de Estudos do Desenvolvimento Sustentável, 2012.

FRIDMAN, Sergio. Palácio Monroe, da construção à demolição. Rio de Janeiro: edição do autor, 2011.

GAZETA WEB. Disponível em: <http://gazetaweb.globo.com/gazetadealagoas/imprimir. php?c=3771>. Acesso em: 24 abr. 2015.

GETTY CONSERVATION INSTITUTE. Disponível em: <www.getty.edu/conservation/about/ mission.html>. Acessos diversos.

GONÇALVES, José Reginaldo dos Santos. A retórica da perda: os discursos do patrimônio cultural no Brasil. Rio de Janeiro: Editora da UFRJ; MEC-Iphan, 2002.

HERNÁNDEZ-MARTÍNEZ, Ascensión. La clonación Arquitectónica. Madrid: Siruela, 2007.

HOBSBAWM, Eric. Era dos extremos: o breve século XX - 1914-1991. São Paulo: Companhia das Letras, 1996.

INSTITUTO DO PATRIMÔNIO HISTÓRICO E ARTÍSTICO NACIONAL. Bens tombados no Brasil. Disponível em: <http://portal.iphan.gov.br/ans.net/tema_consulta.asp?Linha=tc_belas. gif\&Cod=1038>. Acesso em: 21 jul. 2015.

Coletânea de leis sobre preservação do Patrimônio. Rio de Janeiro: IPHAN, 2006.

Processo 860-T-72. Arquivo Noronha Santos. Rio de Janeiro: Iphan, [s.d.].

INSTITUTO ESTADUAL DO PATRIMÔNIO CULTURAL. Disponível em: <www.inepac.rj.gov. br/modules.php?name=Biblioteca $>$. Acessos diversos.

JAUSS. Hans Robert. Toward an Aesthetic of Reception. Twin Cities: University of Minnesota Press, 1982.

JORNAL DO BRASIL. Rio de Janeiro, s.p., 22 out. 1973a.

Rio de Janeiro, s.p., 14 nov. 1973b.

Rio de Janeiro, p. 18, 15 nov. 1973c.

Rio de Janeiro, 17 nov. 1973d. 
Rio de Janeiro, 24 nov. 1973 e.

Rio de Janeiro, 5 set. 1975.

KÜHL, Beatriz Mugayar. Patrimônio industrial: algumas questões em aberto. Arq.urb., n. 3, p. 23-30, jan.-jun. 2010.

KUSHNIR, Beatriz; HORTA, Sandra (Orgs.). Memórias do Rio: o Arquivo Geral da cidade do Rio de Janeiro em sua trajetória republicana. Rio de Janeiro: Imago, 2011.

LEMOS, Carlos A. C. Da taipa ao concreto - crônicas e ensaios e sobre a memória da arquitetura e do urbanismo. São Paulo: Três Estrelas, 2013.

MACEDO, Oigres Leici Cordeiro de. Construção diplomática, missão arquitetônica: os pavilhões do Brasil nas Feiras Internacionais de Saint Louis (1904) e Nova York (1939). 2012. Tese (Doutorado) - Faculdade de Arquitetura e Urbanismo, Universidade de São Paulo, São Paulo, 2012.

MARINS, Paulo César Garcez Marins. Através da rótula - sociedade e arquitetura no Brasil, séculos XVII a XX. São Paulo: Humanitas; FFLCH USP, 2001.

MENESES, Ulpiano Toledo Bezerra de. Fontes visuais, cultura visual, História visual. Balanço provisório, propostas cautelares. Revista Brasileira de História. São Paulo, v. 23, n. 45, p. 11-36, 2003.

Morfologia das cidades brasileiras: introdução ao estudo histórico das cidades brasileiras. Revista USP, São Paulo, n. 30, p.144-155, jun.-ago. 1996.

MONIER, Gerard. O edifício evento, a história da arquitetura contemporânea e a questão do patrimônio. Desígnio: revista de história da arquitetura e do urbanismo, São Paulo: FAUUSP, n. 6, p.11-18, dez. 2006.

MOTTA, Lia. A SPHAN em Ouro Preto - uma história de conceitos e critérios. Revista do Patrimônio Histórico e Artístico Nacional, Rio de Janeiro, n. 22, p. 108-122, 1987.

NETTO, Rafael. In: DECOURT, André. Monroe, final dos anos 60. Foi um Rio que passou em minha vida, 30 nov. 2009. Disponível em: <http://www.rioquepassou.com.br/2009/11/30/ monroe-final-dos-anos-60/>. Acesso em: jun. 2015.

NOBRE, Ana Luiza et al. (Orgs.). Lúcio Costa: um modo de ser moderno. São Paulo: Cosac Naify, 2004.

O GLOBO. Rio de Janeiro, 4 jul. 1974a.

Rio de Janeiro, 6 jul. 1974b.

Rio de Janeiro, 10 jul. 1974c.

Rio de Janeiro, 19 jul. 1974 d.

Rio de Janeiro, s.p., 7 dez. 1973a.

Annals of Museu Paulista. v. 24. n.3. Sept.-Dec. 2016. 
Rio de Janeiro, 11 dez. 1973 b.

Rio de Janeiro, 11 out. 1975.

OLIVEIRA, Maria Luiza Ferreira de. Entre a casa e o armazém, relações sociais e experiência da urbanização, São Paulo, 1850-1900. São Paulo: Alameda Casa Editorial, 2005.

ORIHUELA, José Luis. 80 Claves sobre el futuro del periodismo (Introducción). El Cuaderno, 27 sep. 2011. Disponível em: <http://www.ecuaderno.com/2011/09/27/introduccion-del-libro-80-claves-sobre-el-futuro-del-periodismo/>. Acesso em: 14 dez. 2015.

PAIVA, Celso Lago. Bens tombados destruídos no Brasil. Disponível em: <www.geocities.ws/ lagopaiva/destruid.htm>. Acessos diversos.

PALÁCIO Monroe. O Globo, [s.d.]. Disponível em: <http://infograficos.oglobo.globo.com/rio/ especial-monroe.html>. Acesso em: 10 jun. 2015.

PALÁCIO Monroe e sua destruição. Alma Carioca, 2013. Disponível em: <http://www.almacarioca.com.br/monroe.htm>. Acesso em: 25 jun. 2015.

PALÁCIO Monroe. Por que foi demolido?. Coisas da Arquitetura, 21 abr. 2010. Disponível em: $<$ https://coisasdaarquitetura.wordpress.com/2010/04/21/palacio-monroe-por-que-foi-demolido/>. Acesso em: jun. 2015.

PALÁCIO Monroe, um rasgo de nossa memória. História do Rio, 13 out. 2012. Disponível em: <https://historiadorio.wordpress.com/2012/10/13/historia-do-rio-palacio-monroe-rasgomemoria/>. Acesso em: 25 jun. 2015.

PÊSSOA, José (Org.). Lúcio Costa: documentos de trabalho. Rio de Janeiro: Edições do Patrimônio, 1998.

PREFEITURA DA CIDADE DO RIO DE JANEIRO. Memória da destruição. Rio, uma história que se perdeu (1889-1965). Rio de Janeiro: Secretaria da Cultura; Arquivo da Cidade, 2002.

RABELLO, Sônia. O Estado na preservação de bens culturais - o tombamento. Rio de Janeiro: IPHAN, 2009. (Série Reedições do Patrimônio).

O RIO de antigamente. Disponível em: <http://oriodeantigamente.blogspot.com.br>. Acessos diversos.

O RIO de Janeiro desaparecido. Disponível em: <http://rio-de-janeiro-desaparecido.blogspot. com.br/2011/06/jardim-botanico-da-bica-j-carlos-para.html>. Acesso em: 10 jul. 2015.

RODRIGUES, Marly. Imagens do passado: a instituição do Patrimônio em São Paulo, 19681987. São Paulo: Editora da Unesp; Condephaat; Fapesp; Imprensa Oficial, 2000.

ROVELLY, Pietro. Le Brésil Contemporain. Berlin-Charlottenburg: Adolf Ecksteins Verlag, 191?.

SANTOS, Cecília Rodrigues dos Santos. Problema malposto, problema reposto. In: NOBRE, Ana Luiza et al. (Orgs.). Lúcio Costa: um modo de ser moderno. São Paulo: Cosac Naify, 2004. 
SANTOS, Hélio. [Carta] 22 jul. 1974 [para] O GLOBO, Rio de Janeiro.

SANTOS, Milton. Espaço \& método. São Paulo: Nobel, 1992.

SANTOS, Paulo. Arquitetura e urbanismo na Avenida Central. In: FERREZ, Marc. A Avenida Central e seu álbum. São Paulo: Ex Libris, 1982.

Quatro séculos de Arquitetura. Rio de Janeiro: IAB, 1981.

SEGAWA, Hugo. Arquiteturas no Brasil, 1900-1990. São Paulo: Edusp, 1999.

SILVA, Joana Mello de Carvalho e. O arquiteto e a produção da cidade: a experiência de Jacques Pilon, 1930-1960. São Paulo: Annablume, 2012.

SKRDLA, Harry. Ghostly Ruins. America's forgotten architecture. Princeton: Princeton University Press, 2006.

SKYSCRAPERCITY.COM. Latin American \& Caribbean Forums. Fóruns Brasileiros. Fóruns Gerais. Arquitetura e discussões urbanas. Essa sim foi uma das construções mais sombrias do Brasil: prédio do Elixir de Nogueira. 2008. Disponível em: <www.skyscrapercity.com/ showthread.php?t=565452>. Acessos diversos.

Latin American \& Caribbean Forums. Fóruns Brasileiros. Fóruns Gerais. Arquitetura e discussões urbanas. A história do Palácio Monroe e de sua destruição. 2005. Disponível em: <http://www.skyscrapercity.com/showthread.php?t=242854>. Acesso em: 23 jun. 2015.

SOARES, Alberto Goyena. Memórias de uma cidade paralela: o Rio Antigo nas montagens de uma confraria. 2009. Tese (Doutorado) - Instituto de Filosofia e Ciências Sociais, Universidade Federal do Rio de Janeiro, Rio de Janeiro, 2009.

ZIEGLER, Carl. Fourth Pan American Congress of Architects. Bulletin of Pan American Union, Washington, D.C., 1930. Disponível em: <https://archive.org/stream/bulletinofpaname6531pana/bulletinofpaname6531pana_dju.txt>. Acesso em: 24 jan. 2015.

Artigo apresentado em 28/03/2016. Aprovado em 29/12/2016. 